\title{
Cellular Care and Extracellular Vesicles Therapies of Heart Failure
}

\author{
Alexander Berezin* \\ Department of Internal Medicine, State Medical University for Zaporozhye, Ukraine
}

Submission: March 16, 2019; Published: May 09, 2019

*Corresponding author: Alexander Berezin, Professor, MD, PhD, Consultant of Therapeutic Unit, Internal Medicine Department, State Medical University for Zaporozhye, 26, Mayakovsky Av., Zaporozhye, Postcode 69035, Ukraine

\begin{abstract}
Heart failure (HF) is a major factor contributing to premature death in patients with established cardiovascular (CV) disease. Current cell therapies of HF based on at least two different approaches, in which stem cell transplantation and extracellular vesicles (EV) received from pretreated cells, were used. Although in HF restoring cardiac function aimed improve survival is target of cell therapy, it is not yet yielded whether isolated EVs from circulating progenitor cells, induced pluripotent stem cells (iPSCs), human embryonic stem cells-derived CV progenitors (hESC$\mathrm{Pg}$ ) would be effective translators of reparative signals for cardiac repair. The short communication is depicted the role of different cell strategies in HF. It has emphasized lack of strong evidence of clinical advantages implanted EVs to human cells to iPSCs in HF requires comparison in large clinical trials.
\end{abstract}

Keywords: Heart failure; Cell therapies; Human stem cells; Human progenitors; Progenitor cell-derived extra vesicles

Abbreviations: HF: Heart Failure; CV: Cardiovascular; EV: Extracellular Vesicles; iPSCs: Induced Pluripotent Stem Cells; hESC-Pg: Human Embryonic Stem Cells- Progenitors; iPSCs: Induced Pluripotent Stem Cells

\section{Short Communication}

Heart failure (HF) remains a potent fatal end stage of nature evolution of numerous cardiac diseases with complex and uncertain pathophysiology mechanisms [1,2]. There is evidence that the impaired reparative processes in myocardium affecting cardiac myocytes loss, extracellular matrix remodeling, vasculogenesis, neovascularization, abnormal switch-on of metabolic fetal genes, co-regulation of (pro)-oncogenes, overexpression of oxidative molecules and others could be accompanied with progression of HF regardless of its etiologies [3-5]. Wide range of preclinical and clinical studies depicted the innate molecular pathways of the disease that may be used as therapeutic targets for novel agents recovering reparative capacity of the myocardium in HF [6-8].

Extracellular vesicles (EV) are generally defined as intracellular originated particles shedded from the plasma membrane (micro particles) and released after the fusion of the plasma membranes or formed from endosomes (exosomes) with different size ranges that are usually $100 \mathrm{~nm}$ and less [9]. EVs are secreted by numerous cells with different origin due to different signaling mediators and may unleash favorable effects on cardiac reparation by modulation of the metabolism of target cells by transferring signal proteins, growth factors and various genomic materials [10]. EVs acting as cargo of secreted factors are powerful regu lator of cell-to-cell communications. Moreover, EVs are a component of cell secretom that is under direct and indirect influences of various epigenetic factors (pro-inflammatory cytokines, free radicals, micro RNAs, etc.), which co-expressed in HF and are able to change a capability of EVs to repair tissues $[4,9]$. Indeed, lowered functionality of progenitor cells and weak ability to release EVs with reparative capacity in HF is well established, while the data regarding repair activity of other cells including stem cells, mature cells with different origin are limited [9]. This phenomenon became to be known as progenitor cell dysfunction and it associated with impaired circulating EV immune phenotypes due to imbalance between EVs released form activated and apoptotic precursors [7]. Development and progression of HF strongly associated with elevation of circulating EVs shaping from various populations of the cells including stem cells, progenitor cells and mature endothelial cells, some resident cells, mononuclear cells, adipocytes, cardiac myocytes, that reflects a tenderness of reparative processes and therefore a signature of the EVs may be a marker of severity and prognosis of HF $[11,12]$. In this context, it is not yet yielded whether isolated EVs from circulating progenitor cells, induced pluripotent stem cells (iPSCs), human embryonic stem cells-derived CV progenitors (hESC-Pg) would be effective translators of reparative signals for cardiac repair. 
There is evidence in support of cell-based therapies of HF with stem cells- and progenitor cell-derived EVs could have promising impact on regeneration of target organs in HF $[6,13$ 15]. Kervadec et al. [14] reported that six weeks administration of EVs released by (hESC-Pg) in post-infarct HF model can provide equivalent benefits to administered hESC-Pg and hESC-Pg and EV. Authors revealed that paracrine mechanism might be sufficient to effect functional recovery of target organs in ischemia-induced HF during cell-based therapy period. Adamiak et al. [15] revealed that iPSC-derived EVs demonstrated sufficient cytoprotective properties and induced cardiac repair associated with improved left ventricular function, attenuation of vascularization, and amelioration of cell apoptosis. There is evidence that the EVs received from cardiac progenitor cells, but not from fibroblasts, may improve global cardiac function after injury through suppression of cell apoptosis [16]. Although an ability of iPSCderived CV progenitor cells differentiate in to $\mathrm{CV}$ lineages in vitro was found in early animal investigations [17-19], there are limitations to translate their restoring capabilities (improvement of myocardial tissue and electrical function) into clinical practice due to uncertain efficacy in large clinical trials [20]. However, the cell therapies based on EVs isolation from target cells appears to be promising. Collectively, all these data confirmed the idea that the EVs are probably more optimal co-regulator of endogenous reparative activity of residential cells, neovascularization and enhancing endothelial function than other transplanted cells such as iPSCs and endothelial precursors. Finally, whether cell therapies based on transplantation of iPSCs that may effectively differentiate into mature cardiac myocytes is superior to EVs received from pre-treated precursors or stem cells is not fully clear and requires more investigations in large clinical trials.

\section{Conclusion}

In conclusion, there is not strong evidence regarding clinical advantages of implanted EVs as an active component of the paracrine secretion by human cells to iPSCs in translation regenerative medicine in HF. However, the limitations of human iPSCs transplantation create expectations that EVs received from various cells could be safer and probably more effective than care based on pluripotent cell technologies.

\section{References}

1. Hsu JI, Ziaeian B, Fonarow GC (2017) Heart Failure With Mid-Range (Borderline) Ejection Fraction: Clinical Implications and Future Directions. JACC Heart Fail 5(11): 763-771.

2. Sweitzer NK, Lopatin M, Yancy CW, Mills RM, Stevenson LW (2008) Comparison of clinical features and outcomes of patients hospitalized with heart failure and normal ejection fraction $(>$ or $=55 \%)$ versus those with mildly reduced ( $40 \%$ to $55 \%$ ) and moderately to severely reduced (<40\%) fractions. Am J Cardiol 101(8): 1151-1156.

3. Popovic D, Arena R, Guazzi M (2018) A flattening oxygen consumption trajectory phenotypes disease severity and poor prognosis in patients with heart failure with reduced, mid-range, and preserved ejection fraction. Eur J Heart Fail 20(7): 1115-1124.

4. Berezin A (2016) Epigenetics in heart failure phenotypes. BBA Clin 6: 31-7.
5. Oikonomou E, Mourouzis K, Fountoulakis P, Papamikroulis GA, Siasos G, et al. (2018) Interrelationship between diabetes mellitus and heart failure: the role of peroxisome proliferator-activated receptors in left ventricle performance. Heart Fail Rev 23(3): 389-408.

6. Cabral J, Ryan AE, Griffin MD, Ritter T (2018) Extracellular vesicles as modulators of wound healing. Adv Drug Deliv Rev 129: 394-406.

7. Berezin A (2016) Metabolic memory phenomenon in diabetes mellitus: Achieving and perspectives. Diabetes Metab Syndr $10(2$ Suppl 1): S176-183.

8. El Harane N, Kervadec A, Bellamy V, Pidial L, Neametalla HJ, et al. (2018) Acellular therapeutic approach for heart failure: in vitro production of extracellular vesicles from human cardiovascular progenitors. Eur Heart J 39(20): 1835-1847.

9. Berezin AE (2017) Microparticles in Chronic Heart Failure. Adv Clin Chem 81:1-41.

10. Durcin M, Fleury A, Taillebois E, Hilairet G, Krupova Z, et al. (2017) Characterisation of adipocyte-derived extracellular vesicle subtypes identifies distinct protein and lipid signatures for large and small extracellular vesicles. J Extracell Vesicles 6(1): 1305677.

11. Berezin AE, Kremzer AA, Martovitskaya YV, Samura TA, Berezina TA (2014) The predictive role of circulating microparticles in patients with chronic heart failure. BBA Clin 3: 18-24.

12. Berezin AE, Kremzer AA, Berezina TA, Martovitskaya YV (2015) Pattern of circulating microparticles in chronic heart failure patients with metabolic syndrome: Relevance to neurohumoral and inflammatory activation. BBA Clin 4: 69-75.

13. Keerthikumar S, Chisanga D, Ariyaratne D, Al Saffar H, Anand S, et al (2016) ExoCarta: A Web-Based Compendium of Exosomal Cargo. J Mol Biol 428(4): 688-692.

14. Kervadec A, Bellamy V, El Harane N, Arakélian L, Vanneaux V, et al. (2016) Cardiovascular progenitor-derived extracellular vesicles recapitulate the beneficial effects of their parent cells in the treatment of chronic heart failure. J Heart Lung Transplant 35(6): 795-807.

15. Adamiak M, Cheng G, Bobis-Wozowicz S, Zhao L, Kedracka-Krok S, et al. (2018) Induced Pluripotent Stem Cell (iPSC)-Derived Extracellular Vesicles Are Safer and More Effective for Cardiac Repair Than iPSCs. Circ Res 122(2): 296-309.

16. Barile L, Lionetti V, Cervio E, Matteucci M, Gherghiceanu M, et al. (2014) Extracellular vesicles from human cardiac progenitor cells inhibit cardiomyocyte apoptosis and improve cardiac function after myocardial infarction. Cardiovasc Res 103(4): 530-541.

17. Mauritz C, Martens A, Rojas SV, Schnick T, Rathert C, et al. (2011) Induced pluripotent stem cell (iPSC)-derived Flk-1 progenitor cells engraft, differentiate, and improve heart function in a mouse model of acute myocardial infarction. Eur Heart J 32(21): 2634-241.

18. Higuchi T, Miyagawa S, Pearson JT, Fukushima S, Saito A, et al. (2015) Functional and Electrical Integration of Induced Pluripotent Stem Cell-Derived Cardiomyocytes in a Myocardial Infarction Rat Heart. Cell Transplant 24(12): 2479-2489.

19. Ja KP, Miao Q, Zhen Tee NG, Lim SY, Nandihalli M, et al. (2016) iPSC-derived human cardiac progenitor cells improve ventricular remodelling via angiogenesis and interstitial networking of infarcted myocardium. J Cell Mol Med 20(2): 323-332.

20. Chung ES, Miller L, Patel AN, Anderson RD, Mendelsohn FO, et al. (2015) Changes in ventricular remodelling and clinical status during the year following a single administration of stromal cell-derived factor- 1 nonviral gene therapy in chronic ischaemic heart failure patients: the STOP-HF randomized Phase II trial. Eur Heart J 36(33): 2228-2238. 


\section{Your next submission with Juniper Publishers} will reach you the below assets

- Quality Editorial service

- Swift Peer Review

- Reprints availability

- E-prints Service

- Manuscript Podcast for convenient understanding

- Global attainment for your research

- Manuscript accessibility in different formats ( Pdf, E-pub, Full Text, Audio)

- Unceasing customer service

Track the below URL for one-step submission https://juniperpublishers.com/online-submission.php 